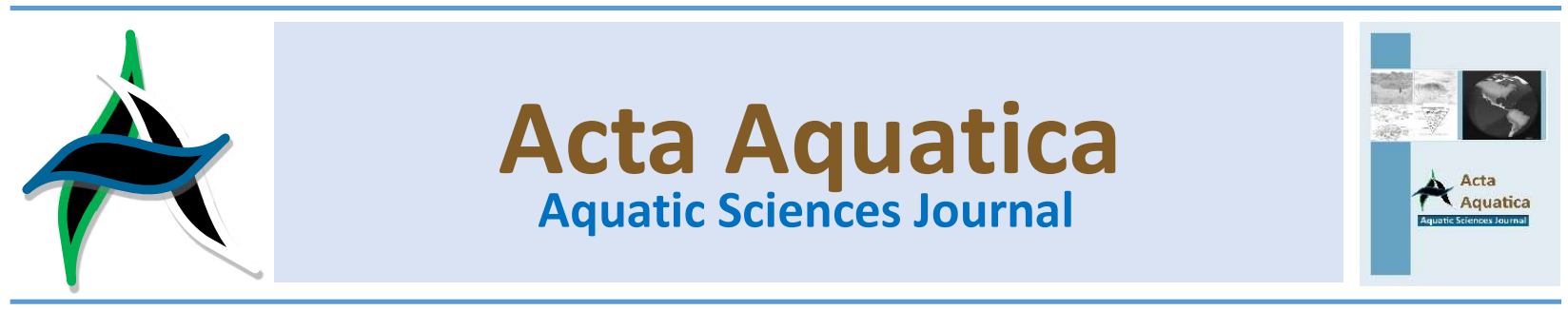

\title{
Kajian kinerja pertumbuhan dan kelangsungan hidup ikan kerapu macan (Ephinephelus fuscogusttatus) menggunakan pakan hewani yang berbeda
}

\section{Study of growth and survival performance of tiger grouper (Ephinephelus fuscogusttatus) using different animal feeds}

\author{
Munawwar Khalil $^{\mathrm{a}}$, Salamah ${ }^{\mathrm{a}}$ Zumairia $^{\mathrm{a}}$ dan Muliania* \\ ${ }^{a}$ Program Studi Akuakultur, Fakultas Pertanian, Universitas Malikussaleh
}

\begin{abstract}
Abstrak
Ikan Kerapu macan (Epinephelus fuscoguttatus) adalah ikan ekonomis penting yang benihnya masih mengandalkan hasil tangkapan dari alam. Beberapa spesies ikan kerapu sangat potensial dibudidayakan karena pertumbuhannya cepat, konversi pakan yang efisien dan nilai jualnya yang tinggi. Tujuan penelitian ini yaitu untuk mengetahui kinerja pertumbuhan dan kelangsungan hidup ikan kerapu macan (Epinephelus fuscoguttatus) menggunakan pakan hewani yang berbeda. Rancangan penelitian yang digunakan dalam penelitian ini adalah Rancangan Acak Lengkap (RAL) dengan 3 perlakuan 3 ulangan. Perlakuan yang diberikan yaitu: perlakuan A (Bekicot), perlakuan B (Usus Ayam) dan perlakuan C (Ulat Maggot). Parameter yang diamati adalah pertambahan panjang, pertambahan bobot, kelangsungan hidup, respon pakan dan kualitas air. Hasil penelitian ini menunjukkan bahwa pertambahan panjang tertinggi terdapat pada perlakuan $\mathrm{C}$ yaitu $4,04 \mathrm{~cm}$ dan pertambahan bobot tertinggi tedapat pada perlakuan C yaitu 3,73 gram. Kelangsungan hidup ikan kerapu macan selama penelitian adalah $100 \%$. Nilai kualitas air selama penelitian ini masih dalam kisaran yang baik untuk pertumbuhan dan kelangsungan hidup ikan kerapu macan yaitu suhu berkisar $\left(28,6-31,8^{\circ} \mathrm{C}\right)$, $\mathrm{pH}(6,7-8,2)$, DO $(6,3-8,1 \mathrm{ppm})$ dan salinitas (23-27 ppt)
\end{abstract}

Kata kunci: Kerapu macan, pakan hewani, pertumbuhan dan kelangsungan hidup

\begin{abstract}
The tiger grouper (Epinephelus fuscoguttatus) is an economically important fish whose fry still relies on natural catches. Several species of grouper are very potential to be cultivated because of their fast growth, efficient feed conversion, and high selling value. The purpose of this study is growth performance and survival rate tiger grouper (Epinephelus fuscoguttatus) used different live feed. The research design used in this study was a Completely Randomized Design with 3 treatments 3 replications and continued with $L S D$ test if there were differences. The treatments given are treatment $A$ (Snail), treatment $B$ (Chicken Intestine), and treatment $C$ (Caterpillar Maggot). Parameters observed were length increase, weight gain, survival, feed response, and water quality. The results of this study indicate that the highest increase was found in the treatment of $C: 4,04$ $\mathrm{cm}$ and the lowest was in treatment $B: 3 \mathrm{~cm}$, the highest weight gain was found in the treatment of $C: 3,73$ grams, and the lowest was in treatment $B: 2,18$ grams. The survival rate for all treatments is $100 \%$. During this study the temperature ranged (28.6-31.8 oC), pH (6.7-8.2), DO (6.3-8.1 ppm), and salinity (2327 ppt).
\end{abstract}

Keywords: growth, live feed, survival rate, tiger grouper.

* Korespondensi: muliani

Prodi Akuakultur, Fakultas Pertanian, Universitas Malikussaleh. Kampus utama Reuleut,

Kabupaten Aceh Utara, Aceh, Indonesia.

Tel: +62-645-xxxxx Fax: +62-645-xxxxx.

e-mail:muliani@unimal.ac.id 


\section{Pendahuluan}

\subsection{Latar belakang}

Ikan kerapu macan mempunyai kebiasaan makan hewani (carnivora) dan rakus, sifat kanibalnya akan muncul apabila kekurangan pakan, hidupnya menyendiri dan banyak ditemui pada daerah terumbu karang. Ikan Kerapu macan (Epinephelus fuscoguttatus) adalah ikan ekonomis penting yang benihnya masih mengandalkan hasil tangkapan dari alam. Beberapa spesies ikan kerapu sangat potensial dibudidayakan karena pertumbuhannya cepat, konversi pakan yang efisien dan nilai jualnya yang tinggi, (Zainuddin et al. 2004). Saat ini budidaya ikan kerapu macan dikembangkan secara intensif karena didorong oleh permintaan pasar dan harga jual yang tinggi. Namun dalam usaha budidaya tersebut terkendala dengan pertumbuhan yang lambat, harga pakan yang mahal dan tidak tersedianya pakan secara berkelanjutan. Secara umum pendederan atau pembesaran ikan kerapu macan menggunakan pakan berupa ikan rucah, namun ikan ini tidak selalu tersedia secara berkelanjutan.

Berdasarkan permasalahan tersebut maka perlu dicari alternatif pakan yang murah dan mudah didapat, memiliki protein tinggi serta tersedia secara terus menerus. Salah satu pakan alternatif untuk mengurangi harga pakan yang mahal dan berprotein tinggi serta bisa tersedia secara terus menerus yaitu pemberian pakan hewani. Beberapa jenis pakan hewani yang memiliki protein tinggi dan bisa menunjang laju pertumbuhan ikan kerapu macan (Epinephelus fuscoguttatus) yaitu: Ulat Maggot, Bekicot, dan Usus Ayam.

Ulat Maggot merupakan larva lalat (black soldier) atau serangga bunga, memiliki tekstur yang kenyal, dan kandungan protein yang cukup tinggi, yaitu 42\%-61,42\% (Fahmi, 2015). Bekicot (Achatina fulica) adalah hewan yang memenuhi syarat untuk digunakan sebagai bahan baku pakan ikan karena memiliki nutrisi yang tinggi. Bekicot mengandung protein $59,28 \%$, lemak 3,62\%, serat kasar 2,47\%, kalsium 6,4\% dan fosfor $0,85 \%$. Selain itu, ketersediaannya kontinyu, mudah didapat, serta tidak mengandung racun yang dapat mengganggu kesehatan dan produktivitas benih ikan (Kompiang 1979 dalam Rosalia, et al., 2018). Usus ayam yang selama ini limbah dari pemotongan ayam ternyata mempunyai kandungan nutrisi yang potensial untuk dijadikan sebagai pakan ikan. Kandungan nutrisi usus ayam yaitu Protein 53,1\%, Lemak 29,2 $\%$, Abu $4,6 \%$, dan karbohidrat 2,0\%.

Informasi pemberian pakan hewani berupa usus ayam, maggot dan bekicot untuk kerapu macan belum banyak. Penelitian yang sudah dilakukan pada beberapa jenis ikan antara lain; usus ayam untuk ikan lele (Falahudin et al.,2016), maggot untuk ikan patin (Putri et al., 2019), atraktan bekicot untuk ikan kerapu macan (Ismi dan Khalil, 2014).

Berdasarkan latar belakang tersebut diatas maka perlu dilakukan penelitian tentang kajian kinerja pertumbuhan dan kelangsungan hidup ikan kerapu macan dengan pemberian pakan hewani yang berbeda, sehingga nantinya akan di dapat alternatif pakan untuk ikan kerapu macan yang memiliki nutrisi tinggi, murah dan tersedia secara berkelanjutan.

\subsection{Identifikasi Masalah}

Adapun permasalahan yang sering dijumpai dalam proses budidaya ikan kerapu macan ialah lambatnya laju pertumbuhan serta harga pakan yang tinggi. Ikan kerapu merupakan ikan karnivora yang membutuhkan kandungan gizi yang baik sehingga diperlukan usaha pencarian sumber alternative pakan selain pakan pelet, yaitu pakan yang mampu memenuhi kebutuhan gizi ikan kerapu untuk membantu pertumbuhannya yaitu dengan mencari alternative pakan yang murah, mudah didapatkan dan mudah penanganannya. Beberapa jenis pakan hewani yang mampu meningkatkan pertumbuhan ikan kerapu macan dan mudah di dapatkan dipasar local yaitu ulat maggot, bekicot dan usus ayam.

\subsection{Tujuan dan manfaat}

Penelitian ini bertujuan untuk mengetahui pengaruh pemberian pakan hewani yang berbeda terhadap pertumbuhan dan kelangsungan hidup ikan kerapu macan yang optimal di dalam keramba jaring tancap (pen culture). Hasil penelitian ini diharapkan dapat memberikan manfaat yaitu bagi pembudidaya berupa informasi mengenai kelayakan budidaya pembesaran ikan kerapu macan (Epinephelus fuscoguttatus) dalam keramba jaring tancap serta mampu memberikan gambaran mengenai teknik budidaya agar dapat digunakan secara efesien namun memberikan keuntungan yang maksimal

\section{Metode Penelitian}

\subsection{Waktu dan tempat}

Penelitian ini dilaksanakan di tambak Desa Lancok Kecamatan Syamtalira Bayu kabupaten Aceh Utara dan Laboratorium Hatchery dan teknologi budidaya Fakultas Pertanian Universitas Malikussaleh. Dan dilaksanakan pada bulan agustus 2020 .

\subsection{Bahan dan alat penelitian}

Alat dan bahan yang digunakan antara lain: benih ikan kerapu macan, bekicot, ulat maggot, usus ayam, $\mathrm{pH}$ meter, DO meter, thermometer, refraktometer, keramba tancap, bamboo, timbangan, penggaris dan alat dokumentasi.

\subsection{Rancangan penelitian}

Metode yang digunakan dalam penelitian ini adalah metode eksperimental menggunakan Rancangan Acak Lengkap (RAL) non faktorial dengan 3 perlakuan dan 3 ulangan. Perlakuan yang digunakan adalah sebagai berikut:

Perlakuan $\mathrm{A}=$ Bekicot

Perlakuan $B$ = Usus ayam

Perlakuan $\mathrm{C}=$ Ulat Maggot

\subsection{Prosedur penelitian}

\subsubsection{Persiapan wadah penelitian}

Persiapan wadah berupa keramba jaring tancap dengan ukuran $30 \mathrm{~cm} \times 30 \mathrm{~cm} \times 30 \mathrm{~cm}$ dan lebar mata jaring $0,3 \mathrm{~cm}$ yang akan digunakan untuk memelihara benih selama penelitian. Wadah yang akan digunakan terlebih dahulu disterilkan dengan mencuci keramba tersebut dengan bersih kemudian dijemur sampai kering. 


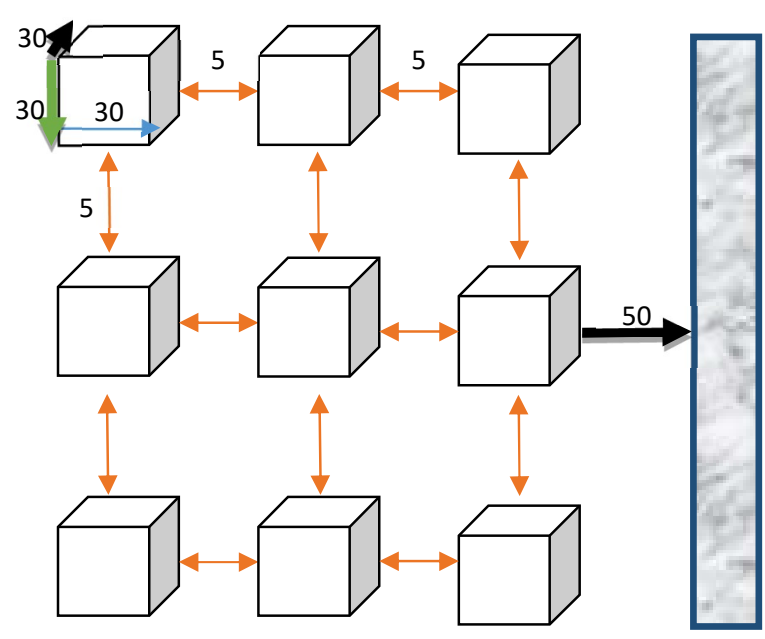

Gambar 5. Posisi Jaring Tancap Di Tambak

\subsubsection{Seleksi Benih}

Benih ikan kerapu macan yang digunakan dalam penelitian ini berasal dari Medan yang berukuran panjang 5-7 $\mathrm{cm}$ dan bobot 0,65 gram. Benih yang digunakan dalam penelitian merupakan benih yang sehat dengan ciri-ciri morfologi tubuh yang lengkap dan tidak terkena penyakit. Pada penelitian ini pakan awal yang diberikan yaitu pellet tenggelam.

\subsubsection{Aklimatisasi}

Benih yang akan digunakan untuk penelitian terlebih dahulu diaklimatisasi selama 1 hari supaya ikan tidak stress dengan kondisi lingkungan yang baru.

\subsubsection{Pemeliharaan Ikan Uji}

Jumlah biota yang digunakan yaitu 120 ekor dimana tiap-tiap perlakuan terdiri dari perlakuan A (10 ekor), B (10 ekor), C (10 ekor) dan D (10 ekor). Ikan yang akan dipelihara ditimbang dan diukur terlebih dahulu untuk mengetahui berat dan panjang awalnya. Menurut Sunyoto (1996) dalam Rambu (2013) pada tahap pedederan ini benih yang ukuran $2-3 \mathrm{~cm}$ dapat ditebar sebanyak $200-250 \mathrm{ekor} / \mathrm{m}^{3}$. Bila telah mencapai ukuran 5-7 cm kepadatan benih yang ditebar menjadi 100 ekor $/ \mathrm{m}^{3}$. Selanjutnya pada tahap pembesaran sampai ukuran konsumsi. Penebaran awal benihnya berukuran 20-50 g dengan kepadatan 50-60 ekor/ $\mathrm{m}^{3}$ dan ukuran benih 100-200 g sebanyak $25-35 \mathrm{ekor} / \mathrm{m}^{3}$.

\subsubsection{Persiapan Pakan}

Pemberian pakan dilakukan setiap hari, sebelum pakan diberikan pakan terlebih dahulu dibersihkan dengan cara: Ulat maggot Didapatkan dari pasar, langsung diberikan untuk ikan. Untuk bekicot dihancurkan cangkangnya terlebih dahulu, diambil isinya, dibersihkan, kemudian dicincang supaya sesuai untuk ukuran mulut ikan. Usus ayam : Didapatkan dari tempat pemotongan ayam, lalu dibersihkan, kemudian dicincang sesuai ukuran mulut ikan.

\subsubsection{Pemberian Pakan}

Pemberian pakan dilakukan setiap hari dengan frekuensi pemberian pakan 3 kali sehari yaitu pada jam 08.00 wib, 13.00 sore pada jam 18.00 wib. Pemberian pakan diberikan sampai kenyang (at satiation) agar tidak terjadi kanibalisme.

\subsection{Parameter uji}

Parameter yang diamati dalam pelaksanaan kegiatan penelitian ini adalah sebagai berikut:

\subsubsection{Pertumbuhan}

Pertambahan panjang diukur juga di ukur 4 kali selama penelitian dengan durasi 7 hari sekali. Pertambahan panjang dihitung dengan menggunakan rumus Effendi, (1997):

Keterangan:

$\mathrm{W}=$ Pertambahan Bobot Mutlak (gr)

$\mathrm{Wt}=$ Bobot Akhir (gr)

Wo = Bobot Awal (gr)

$$
W=W t-W_{0}
$$

Keterangan:

$\mathrm{P} \quad=$ Pertambahan Panjang Mutlak

Pt = Panjang Rata-Rata Pada Hari Ke $\mathrm{t}(\mathrm{cm})$

Po = Panjang Rata-Rata Pada Hari Ke $0(\mathrm{~cm})$

\subsubsection{Kelangsungan hidup}

Pengamatan benih ikan kerapu macan yang hidup dihitung pada awal dan akhir penelitian dengan cara menghitung seluruh jumlah yang masih hidup yaitu dengan menggunakan rumus (Effendi, 1997).

\section{$\mathrm{SR}=\mathrm{Nt} / \mathrm{No} \times 100 \%$}

Keterangan:

$\mathrm{SR} \quad=$ Tingkat Kelangsungan Hidup (\%)

$\mathrm{Nt}=$ Jumlah Biota Yang Hidup Pada Akhir Penelitian (ekor)

No = Jumlah Biota Yang Hidup Pada Awal Penelitian (ekor)

\subsubsection{Parameter kualitas air}

Pengukuran kualitas air selama penelitian dilakukan setiap 7 hari dalam 1 bulan yaitu pada pagi, siang dan sore hari. Parameter yang diukur selama penelitian antara lain suhu, $\mathrm{pH}$, oksigen terlarut (DO) dan salinitas

\subsubsection{Respon pakan}

Respon pakan ikan diamati pada saat pemberian pakan dengan meggunakan stopwatch. Hal ini bertujuan untuk mengetahui pakan yang mana yang duluan dimakan dan dihabiskan pada setiap perlakuan.

\subsection{Analisis data}

Rancangan yang digunakan pada penelitian ini merupakan Rancangan Acak Lengkap (RAL), penelitian dilakukan menggunakan 4 perlakuan dengan 3 kali ulangan. Rancangan yang digunakan berdasarkan persamaan (Steel \& Torrie, 1991), sebagai berikut:

$$
Y i j=\mu+a i+\varepsilon i j
$$

Data hasil penelitian disajikan dalam bentuk tabel dan grafik kemudian dianalisis dengan analysis of variance (ANOVA) dengan menggunakan software SPSS. Apabila terdapat perlakuan yang berbeda nyata ( $\mathrm{F}$ hitung $>\mathrm{F}$ tabel) maka selanjutnya dilakukan uji lanjut dengan menggunakan uji Tukey sedangkan data kualitas air dianalisi secara deskriptif.

\section{Hasil dan Pembahasan}

\subsection{Pertumbuhan ikan kerapu macan}

Berdasarkan hasil penelitian menunjukkan bahwa pemberian pakan hewani yang berbeda terhadap pertambahan panjang ikan kerapu macan memiliki nilai yang berbeda disetiap 
perlakuan. Rata-rata pertambahan panjang selama peneitian dapat dilihat pada Gambar 1

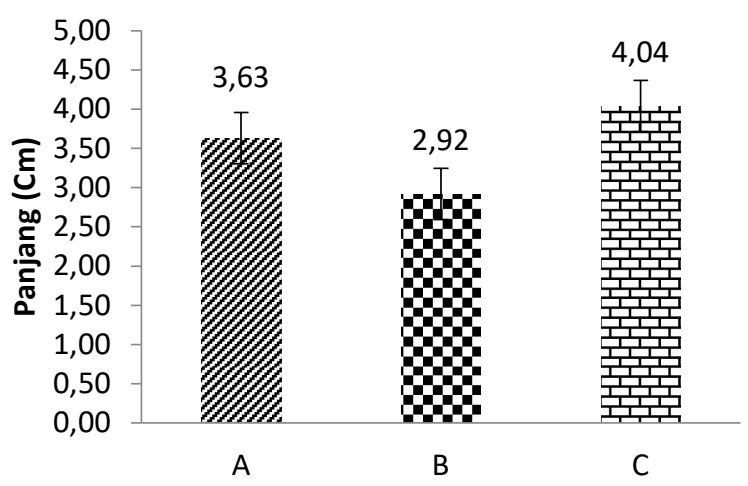

Gambar 1. Rata-rata pertambahan panjang ikan kerapu macan (Epinephelus fuscoguttatus) ( $\mathrm{A}=$ Pemberian pakan bekicot, $\mathrm{B}=$ Pemberian usus ayam, $\mathrm{C}=$ pemberian maggot).

Hasil penelitian menunjukkan bahwa pertambahan panjang tertinggi terdapat pada perlakuan $C$ dengan rata-rata pertambahan panjangnya $4,04 \mathrm{~cm}$ dan pertambahan panjang terendah terdapat pada perlakuan $B$ dengan rata-rata panjangnya $3,00 \mathrm{~cm}$. Pada perlakuan A rata-rata pertambahan panjangnya yaitu $3,63 \mathrm{~cm}$. Hasil analisis statistik dengan uji $\mathrm{F}$ (Anova) menunjukkan bahwa pemberian pakan hewani yang berbeda memberikan pengaruh yang berbeda nyata terhadap pertambahan panjang ikan kerapu macan (Epinephelus fuscoguttatus) dengan nilai $\mathrm{F}_{\text {hitung }}(244,907)>$ nilai $\mathrm{F}$ tabel 0.05 $(5,14)$. Dari hasil uji lanjut Beda Nyata Terkecil (BNT) didapatkan hasil di mana setiap perlakuan berbeda terhadap perlakuan yang lain.

Hasil penelitian menunjukkan bahwa pemberian pakan hewani yang berbeda berpengaruh terhadap pertambahan bobot ikan kerapu macan (Epinephelus fuscoguttatus) pada masing-masing perlakuan. Rata- rata pertambahan bobot ikan dapat dilihat pada Gambar 2.

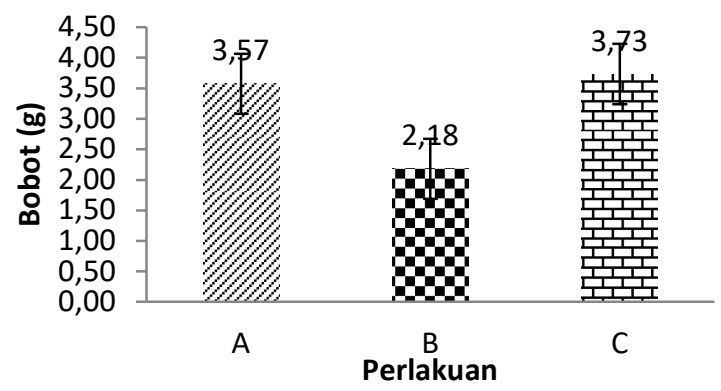

Gambar 2. Rata-rata pertambahan bobot ikan kerapu macan (Epinephelus fuscoguttatus) ( $\mathrm{A}=$ Pemberian pakan bekicot, $\mathrm{B}=$ (Pemberian pakan usus ayam), $\mathrm{C}=$ (pemberian pakan maggot).

Hasil peneltian menunjukkan bahwa pertambahan bobot ikan kerapu macan tertinggi terdapat pada perlakuan $C$ dengan rata-rata 3,73 gram, pertambahan bobot pada perlakuan $A$ rata-rata 3,57 gram dan pertambahan bobot terendah terdapat pada perlakuan B dengan rata rata 2,18 gram. Berdasarkan hasil analisis statistik dengan uji $F$ (Anova) menunjukkan bahwa pemberian pakan alami yang berbeda menunjukkan pengaruh berbeda nyata terhadap pertumbuhan bobot ikan kerapu dengan nilai $F_{\text {hitung }}(3376.569)>$ nilai $F$ tabel 0.05 (5.14). Dari hasil uji Least Significance Different (LSD) atau uji Beda Nyata Terkecil (BNT) menunjukkan bahwa perlakuan terbaik terdapat pada perlakuan $\mathrm{C}$.

Pertumbuhan adalah penambahan ukuran, bobot atau panjang dalam kurun waktu tertentu yang dipengaruhi oleh ketersediaan pakan (Rezeki et al., 2014). Pertumbahan paling baik pada penelitian ini baik pertambahan panjang maupun pertambahan bobot terdapat pada perlakuan $\mathrm{C}$ (pemberian ulat maggot), dengan nilai pertambahan panjang mencapai $4,04 \mathrm{~cm}$ dan bobot 3,73 gram. Hal ini dikarenakan protein yang terkandung dalam ulat maggot sudah memenuhi untuk kebutuhan ikan kerapu macan sehingga dapat memicu pertumbuhan yang optimal. Kandungan protein ulat maggot yaitu $42 \%-61,42 \%$. Hal ini sesuai dengan pendapat Laining et al, (2003) yang menyatakan bahwa ikan kerapu macan ukuran 5-8 $\mathrm{cm}$ membutuhkan kandungan protein $48 \%$. Pemberian salah satu pakan hewani berupa ulat maggot membuktikan bahwa kualitas gizi pakan lebih seimbang sehingga ikan dapat memanfaatkan asupan nutrisi dari pakan dengan baik dan memenuhi kebutuhan gizi yang dibutuhkan sehingga berpengaruh terhadap pertumbuhan. Faktor pertumbuhan juga sangat dipengaruhi oleh kemampuan ikan dalam mencerna dan memanfaatkan pakan dengan baik. Hal ini sesuai dengan pendapat Sucipto dan Prihartono (2005) dalam Setiawan (2011), yang menyatakan bahwa peningkatan penambahan bobot tubuh ikan sangat berkaitan dengan kemampuan ikan dalam memanfatkan dan mencerna pakan yang diberikan dan pakan itu sendiri akan bermanfaat dengan baik apabila faktorfaktor lainnya terpenuhi.

Pertambahan bobot dan panjang terendah terdapat pada perlakuan B (pemberian usus ayam) dengan rata- rata pertambahan panjang dan bobot selama penelitian yaitu $3 \mathrm{~cm}$ dan 2,18 gram. Rendahnya Pertambahan panjang maupun pada perlakuan ini dikarenakan pakan yang diberikan berupa usus ayam tidak sesuai dengan kandungan nutrisi yang dibutuhkan oleh ikan kerapu macan, sehingga pertambahan ikan kerapu tidak maksimal. Kekurangan protein dalam pakanakan mengakibatkan pertumbuhan yang negatif karena protein yang disimpan di dalam jaringan otot akan dirombak menjadi sumber energi sehingga pertumbuhan ikan menjadi terhambat ataupun dalam proses biokimiawinya. Hal ini sesuai dengan pendapat Afrianto dan Liviawati (2005), menyatakan bahwa penggunaan protein seoptimal mungkin sangat penting dalam budidaya ikan.

Rata-rata pertambahan bobot dan panjang pada perlakuan A (pemberian pakan hewani bekicot) memiliki nilai pertambahan tergolong baik bila dibandingkan dengan perlakuan B, akan tetapi kurang baik bila dibandingkan dengan perlakuan C. Nilai pertambahan panjang mencapai $3,63 \mathrm{~cm}$ dan bobot $3,57 \mathrm{gram}$. Hal ini diduga protein yang terkandung dalam bekicot melebihi kebutuhan ikan kerapu macan sehingga pertambahan baik panjang maupun bobot menjadi terhambat.

Kelebihan protein dalam pakan akan mengakibatkan ikan memerlukan energi ekstra untuk melakukan proses metabolisme dan mengeluarkan amoniak sebagai senyawa yang bersifat racun sehingga energi yang digunakan untuk pertumbuhan ikan akan berkurang. Menurut Hepner (1990) dalam Faridah (2008), menyatakan bahwa protein dibutuhkan untuk pertumbuhan, pemeliharaan jaringan tubuh, pembentukan enzim dan hormon serta antibodi dalam tubuh. Protein juga berfungsi sebagai sumber energi, kualitas dan kuantitas protein akan mempengaruhi pertumbuhan. Jika kebutuhan protein tidak dapat tercukupi dalam pakan maka akan terjadi penghentian pertumbuhan karena ikan akan menggunakan kembali protein dari beberapa jaringan untuk mempertahankan fungsi dari jaringan yang lebih vital, akan tetapi jika suplai protein terlalu berlebih maka energi yang 
digunakan untuk proses deaminasi asam amino akan meningkat sehingga mengurangi energi untuk pertumbuhan.

\subsection{Kelangsungan hidup ikan kerapu macan}

Hasil penelitian pemberian pakan hewani yang berbeda tidak berpengaruh terhadap tingkat kelangsungan hidup (Survival rate). Pemeliharaan ikan selama 30 hari tidak mengalami kematian sehingga tingkat kelangsungan hidup ikan mencapai $100 \%$. Ikan kerapu macan selama pemeliharaan dapat hidup dengan baik pada setiap wadah dengan pemberian pakan hewani yang berbeda. Hal ini dikarenakan ikan kerapu macan selama penelitian dapat memanfaatkan pakan hewani dengan baik.

Zainuddin et al. (2004) menyatakan bahwa ikan kerapu macan merupakan ikan yang tergolong buas (carnivora) yang rakus, sifat kanibalnya akan muncul apabila kekurangan pakan, hidupnya menyendiri dan banyak ditemui pada daerah terumbu karang. Faktor lain yang menyebabkan ikan yang hidup selama penelitian bisa mencapai $100 \%$ selain dapat memanfaatkan pakan dengan baik juga disebabkan oleh lingkungan budidaya diantaranya kualitas air yang optimal sebagai media hidup ikan kerapu macan. Hal ini sesuai dengan pendapat Effendi, (2003) yang menyatakan bahwa selain ketersediaan pakan, sifat fisika kimia air dilingkungan merupakan salah satu faktor penting yang mempengaruhi kelangsungan hidup ikan.

\subsection{Parameter kualitas air}

Berdasarkan hasil pengukuran kualitas air media pemeliharaan ikan kerapu macan (Ephinepelus fuscoguttatus), secara umum berada pada kisaran optimal untuk pemeliharaan ikan kerapu macan. Berikut nilai parameter kualitas air dapat dilihat pada Tabel 1.

Tabel 1. Parameter kualitas air.

\begin{tabular}{cc}
\hline Parameter & Hasil Pengamatan \\
\hline Suhu $\left({ }^{\circ} \mathrm{C}\right)$ & $28,6-31,8$ \\
\hline $\mathrm{pH}$ & $6.5-8,2$ \\
\hline $\mathrm{DO}(\mathrm{ppm})$ & $6,2-8.1$ \\
\hline Salinitas $(\mathrm{ppt})$ & $23-27$ \\
\hline
\end{tabular}

Berdasarkan Tabel 1 diketahui bahwa kuliatas air pada saat pemeliharaan ikan kerapu macan tergolong baik. Hal ini sesuai dengan pendapat Gusrina (2008) yang menyatakan bahwa syarat kualitas air untuk budidaya adalah suhu $20-30^{\circ} \mathrm{C}$, DO, >5 ppm, pH 6-9, Salinitas 6-29 ppt. Suhu ideal untuk pemeliharaan ikan kerapu macan berkisar antara $27-28,5^{\circ} \mathrm{C}$ (Sari et, al. 2009).

Hasil penelitian menunjukkan $\mathrm{pH}$ air selama penelitian berkisar antara 6.5-8.2. $\mathrm{pH}$ ideal untuk pemeliharaan ikan kerapu macan berkisar antara 7-8 (Sari et, al. 2009). Suatu perairan yang ber $\mathrm{pH}$ rendah dapat mengakibatkan aktivitas pertumbuhan menurun atau ikan menjadi lemah serta lebih mudah terinfeksi penyakit dan biasanya diikuti dengan tingginya tingkat kematian ikan (Akbar dan Sudaryanto, 2001).

Oksigen terlarut (DO) pada penelitian ini berkisar antara 5.7 - $8.3 \mathrm{mg} / \mathrm{L}$. Hal ini sesuai dengan DKP (2007), menyatakan bahwa kandungan oksigen terlarut optimal yang menunjang pemeliharaan ikan kerapu macan berkisar dari 4-8 mg/L. Salinitas air selama penelitian berkisar antara 23-27 ppt. Menurut Tinggal et al. (2005), parameter kualitas air untuk budidaya ikan kerapu macan yaitu suhu $27-29{ }^{\circ} \mathrm{C}$, salinitas $26-$ 33 ppt, oksigen terlarut $>5$ ppm, dan pH 7,0-8,2.

\subsection{Respon makan ikan}

Hasil penelitian menunjukkan bahwa terdapat perbedaan respon terhadap ketiga jenis pakan, baik berupa waktu maupun banyaknya pakan yang dimakan. Pada perlakuan bekicot respon ikan untuk mendekatkan pakan yaitu 0,6 detik dan usus ayam 0,7 detik, sedangkan untuk ulat maggot 0,10 detik. Dari waktu dapat dilihat bahwa Ikan kerapu menyukai pakan yang berbau amis dibandingkan dengan pakan yang bergerak. Hal ini sesuai dengan pendapat Carton dan Montgomery, (2003) menyatakan bahwa bau yang diterima organ penciuman akan mengkondisikan ikan untuk melakukan suatu respons dengan cepat dan efisien terhadap sumber bau makanan tanpa melakukan penyeleksian terhadap informasi bau tersebut sebagai suatu isyarat yang komplek. Sedangkan untuk pakan yang bergerak, ikan kerapu ini juga menyukainya akan tetapi lebih diutamakan untuk pakan yang bau amis.

Adapun banyak pakan yang dihabiskan selama penelitian yaitu berbeda-beda, karena berat antara ketiga jenis pakan tersebut berbeda. Bekicot dan usus ayam ini merupakan pakan jenis dingin yang banyak mengandung unsur air yang berenergi, sedangkan untuk ulat maggot itu mengandung unsur air lebih sedikit ketimbang usus ayam dan bekicot. Maka dari sebab itu pakan ulat maggot lebih sedikit dihabiskan dalam penelitian ini. Dalam penelitian ini pakan bekicot yang dihabiskan selama penelitian yaitu 360 gram, untuk pakan usus ayam hampir sama dengan bekicot yaitu 340 gram, sedangkan untuk pakan ulat maggot jauh berbeda antara bekicot dan usus ayam yaitu 270 gram.

\section{Kesimpulan}

Pemberian pakan hewani yang berbeda berpengaruh nyata terhadap pertumbuhan dan tidak berpengaruh nyata terhadap tingkat kelangsungan hidup ikan kerapu macan. Pertumbuhan paling baik terdapat pada perlakuan C (maggot) dengan tingkat pertumbuhan yaitu panjang $4.04 \mathrm{~cm}$ dan bobot 3,73 gram. Kualitas air media pemeliharaan ikan kerapu macan berada pada kisaran optimal, yaitu suhu: $28,6-31,8^{\circ} \mathrm{C}, \mathrm{pH}: 6,7$ $-8,2$, DO: 6,3-8.1mg/l dan salinitas: 23-26 ppt.

\section{Bibliografi}

Afrianto, E., dan Liviawati, E. 2005. Pakan Ikan. Yogyakarta: Penerbit Kanisius.

Akbar, S dan Sudaryanto. 2001. Pembenihan dan Pembesaran Kerapu Bebek. Penebar Swadaya. Jakarta.

Carton AG, Montgomery, JC. 2003. Evidence of A Rheotactic Component in The Odour Search Behaviourof Freshwater Eels. Jurnal of Fish Biology (62): 501-516.

Effendie, MI. 1997. Biologi Perikanan, Yayasan Pustaka Nusantara. Yogyakarta.

Effendi, H. 2003. Telaah Kualitas Air. Kanisius. Yokyakarta.

Fahmi, M.R. 2015. Optimalisasi proses biokonversi dengan menggunakan mini-larva Hermetia illucens untuk memenuhi kebutuhan pakan ikan. In Masyarakat Biodiversitas Indonesia (Vol. 1, pp. 139-144).

Falahudin, I., Syarifah, S., \& Rahmalia, M. 2016. Pengaruh jenis pakan usus ayam dan ampas tahu terhadap pertumbuhan lele dumbo (Clarias gariepinus). Jurnal Biota, 2(2): 132-137.

Faridah, N. 2008. Pertumbuhan Patin Yang diberikan Pakan Keong Mas Hasil Pelunakan dengan Ekstrak Daun Pepaya sebagai Protein Tambahan. Skripsi. Bogor: Institut Pertanian Bogor. 
Gusrina. 2008. Budidaya Ikan Jilid 2. Direktorat Pembinaan Sekolah Menengah Kejuruan Direktorat Jenderal Manajemen Pendidikan Dasar dan Menengah Departemen Pendidikan Nasional. Jakarta.

Ismi, N \& Khalil, M. 2014. Penambahan atraktan ekstrak bekicot, keong mas, dan siput air tawar dalam pakan untuk meningkatkan pertumbuhan benih Ikan kerapu macan (Epinephelus fuscoguttatus). Acta aquatica. 1(1): 7-13.

Laining, A., Kabangnga, N., Usman. (2003). Pengaruh Protein Pakan Yang Berbeda Terhadap Koefisien Kecernaan Nutrien Serta Performansi Biologis Kerapu Macan, (Epinephelus fuscoguttatus), dalam Keramba Jaring Apung. Jurnal Penelitian Perikanan Indonesia, 9(2): 2934.

Putri W.H, Harris., H \& Haris R.B.K. Kombinasi maggot pada pakan komersil terhadap pertumbuhan, kelangsungan hidup, FCR dan biaya pakan ikan patin siam (Pangasius hypophthalmus). Jurnal IImu IImu Perikanan dan Budidaya Perairan (JIPBP): Fakultas Perikanan dan Kelautan Universitas PGRI Palembang. 14(1): 7-16.

Rezeki, F., Yusni, E., Lesmana, I. 2014. Pemberian pakan berbeda terhadap pertumbuhan belut sawah (Monopterus albus Zuieuw) yang dipelihara didalam tong. Fakultas Pertanian Universitas Sumatera Utara.

Rosalia, D., Yudha, I.G., Santoso, L. 2018. Kajian Pemanfaatan Tepung Bekicot (Achantina fulica) Sebagai Bahan Baku Pakan Benih Ikan Gabus Channa striata (Bloch, 1973). Lppm. Unila, Lampung.

Sari WP, Agustono dan Yudi C. 2009. Pemberian Pakan dengan Energi yang BerbedaTerhadap Pertumbuhan Benih Ikan Kerapu Tikus (Cromileptes altivelis). Fakultas Perikanan Universitas Hang Tuah Surabaya. Surabaya. 18 hal.

Steel, P. G. D. and J. H. Torrie. 1991. Prinsip dan Prosedur Statistika suatu Pendekatan Geometrik. Terjemahan B. Sumantri. PT Gramedia. Jakarta. 